\title{
Article
}

\section{Explicit instruction of spoken requests: an examination of pre-departure instruction and the study abroad environment}

Halenko, Nicola and Jones, Christian

Available at http://clok.uclan.ac.uk/17884/

Halenko, Nicola ORCID: 0000-0002-9906-6418 and Jones, Christian (2017) Explicit instruction of spoken requests: an examination of pre-departure instruction and the study abroad environment. System, 68 . pp. 26-37. ISSN 0346-251X

It is advisable to refer to the publisher's version if you intend to cite from the work. http://dx.doi.org/10.1016/j.system.2017.06.011

For more information about UCLan's research in this area go to http://www.uclan.ac.uk/researchgroups/ and search for <name of research Group>.

For information about Research generally at UCLan please go to http://www.uclan.ac.uk/research/

All outputs in CLoK are protected by Intellectual Property Rights law, including Copyright law. Copyright, IPR and Moral Rights for the works on this site are retained by the individual authors and/or other copyright owners. Terms and conditions for use of this material are defined in the policies page. 
Explicit instruction of spoken requests: an examination of pre-departure instruction and the study abroad environment.

\begin{abstract}
The aim of this study is to evaluate the impact of explicit interventional treatment on developing pragmatic awareness and production of spoken requests in a study abroad context (taken here to mean those studying/using English for academic purposes in the UK) with Chinese learners of English at a British higher education institution. The study employed an experimental design over a 6 month period with 34 students assigned to either an explicitly instructed group or a control group receiving no instruction. Instruction took place prior to departure for the UK and performance was measured based on a pre-, immediate and delayed post-test design using a computer-animated production test (CAPT); an oral discouse completion test (DCT). The findings revealed that explicit instruction facilitated development of pragmatically appropriate request language in the short term and, to some extent, this was sustained over time. The CAPT data was also analysed in order to examine the use of internal and external modification of requests by each group. Results demonstrate that the explicit instruction group used significantly more modification at the immediate post-test stage but that the control group used significantly more at the delayed test stage.
\end{abstract}

\title{
1. Introduction
}

Whilst the interest in the development of pragmatic competence during study abroad (SA) sojourns continues to grow, this is not matched by empirical investigations with a predeparture focus, despite consensus of the benefits SA preparation programmes can offer (e.g., Cohen and Shively, 2007; Paige, Cohen and Shively, 2004). Learners engaging in SA sojourns are challenged to function in a linguistically and socially appropriate way in an 
unfamiliar environment within which the expected pragmalinguistic and sociopragmatic conventions may vary considerably from their home countries. These challenges have been shown to be successfully facilitated through pedagogical intervention, within the at-home or SA contexts (see Jeon and Kaya, 2006; Taguchi, 2014; 2015 for reviews on instructional effects). Studies situating interventions during pre-departure programmes are still greatly underexplored.

When examining sustainability of instruction once learners are active in the SA period, Bardovi-Harlig (2013) considers there to be a complex interplay of influential factors at play including learner proficiency, individual differences and interaction with the environment. Indeed, in the current body of interlanguage pragmatics literature, each of these factors has been shown to play a decisive, but not exclusive, role when examining pragmatic development; learner proficiency (Félix-Brasdefer, 2007; Schauer, 2009); individual learner differences (Ranta and Meckelborg, 2013; Taguchi, 2008) and L2 interaction (Bella, 2011; Shively, 2013). The present study examines the effects of an explicit instructional treatment of request language, with a focus on tracking learners' performance at the pre-departure and study abroad stages.

\section{Literature review}

\subsection{Developing requests in a study abroad context}

The teaching of foreign languages often embed SA experiences which include the presence or absence of formal pragmatic instruction in order for language learners to enhance their language skills and raise cross-cultural awareness. SA investigations which specifically incorporate pragmatic instruction rarely appear in research, whilst SA investigations which do not feature structured pragmatic input dominate the literature. SA programmes may be 
beneficial for learners due to frequent exposure to local norms, target language input, and the associated opportunities to integrate this knowledge into their own communicative practices. This has been tested within a range of pragmatic features: awareness of address terms and colloquial expressions (Kinginger, 2008); humour (Shardakova, 2013); informal/formal pronouns (Kinginger and Farrell, 2004); polite and plain forms (Iwasaki, 2010); speech acts (Félix-Brasdefer, 2004; Schauer, 2009; Shively, 2011; Taguchi, 2008); formulaic language (Bardovi-Harlig and Bastos, 2011) and listener responses (Shively, 2015). Contradicting expectations, the majority of results suggest that a positive link between the SA experience and improved pragmatic competence cannot always be made.

Reviewing the literature on the acquisition of request language in the SA context reveals a number of developmental trends towards the L2 norm. First, there is evidence of positive shifts to more target-like selection of request strategies over time. This evidence includes studies which show the use of more indirect requests in English-speaking host environments (Code and Anderson, 2001, Schauer, 2007, Woodfield, 2012) and more direct requests in Spanish and Chinese contexts (Félix-Brasdefer, 2007; Li, 2014; Shively, 2011). Second, greater use of formulaic language in requests has been observed over time (BardoviHarlig and Bastos, 2011; Barron, 2003; Schauer, 2007; Shively, 2011). Finally, several studies (e.g. Barron, 2003, Code and Anderson, 2001, Li, 2014, Schauer, 2004, Woodfield, 2012) report increased mitigation through internal modification (mitigation devices within the head act such as downtoners e.g. 'possibly', or downgraders e.g. 'could') and external modification devices (surrounding the head act, serving to further absorb the impact of the impending imposition such as alerters e.g. 'Excuse me', or apologies e.g. 'sorry'). Beginning with internal modification, this is generally shown to be more challenging for learners with a number of studies reporting an underuse of internal request modifiers or little developmental change in use (Schauer, 2007, 2009; Li, 2014; Woodfield, 2008, 2012; Woodfield and 
Economidou-Kogetsidis, 2010) which may be due to processing complexity, particularly in the early stages of L2 development (Ellis, 1992; Rose, 2000, Trosborg, 1995). Concerning external modification, Li (2014), Schauer (2009) and Woodfield (2012) observed more targetlike patterns of development, though overuse has also been reported (Woodfield and Economidou-Kogetsidis, 2010). These empirically-reported features broadly align to the developmental stages of request production, as outlined by Kasper and Rose (2002), though this improved performance still falls short of target-like levels in most cases.

\subsection{Influential factors on request performance}

A closer examination of these developmental trends reveals the degree of change across request components may vary (Schauer, 2007, 2009; Woodfield, 2008, 2012; Woodfield and Economidou-Kogetsidis, 2010). However, changes attributable to individual differences (Kinginger, 2013) including proficiency and length of stay, have been the most frequently examined variables, in addition to first language transfer. For instance, target-like levels of internal modification of requests have been reported to increase in line with proficiency levels with both at-home and study abroad learners (Barron, 2007; Hill, 1997; Kasper and Rose, 2002; Octu and Zeyrek, 2008). Al-Gahtani and Roever (2013) found low proficiency ESL learners were more likely to produce shorter requests with little evidence of delaying the core request due to processing load, limited vocabulary, and grammatical resources available at this level.

Length of stay in the target language has also been reported in several studies as indicative of failure to appropriately modify request language to L2 norms. Both Bataller (2010) and $\mathrm{Li}$ (2014) reported that restricted four and five month respective sojourns were contributory factors for the learners' inability to achieve target-like levels of strategy selection and request modification. These results support Schauer's (2009) earlier conclusion that stays 
of nine months or more yield more positive results when examining the development of request production. Partially contradicting the above findings, Beltran (2014) examined the awareness and production of request language with 104 non-native, long-term UK residents. Results showed length of stay had no effect when assessing the grammatical accuracy of requests, and longer-term residents of between five and sixteen years evidenced poorer pragmatic awareness than those resident for less than six months. Length of stay was, however, influential in producing a wider range and variety of mitigators, in particular external modification, but this was not found to be statistically significant. Considering the recognition and production of conventional expressions in an L2 context, Bardovi-Harlig and Bastos (2011) also report length of stay has no significant influence on the recognition and production of high frequency expressions, such as those used for making a request. In fact, intensity of interaction (for recognition) and proficiency (for both recognition and production) were shown to be the key variables.

Several studies have cited negative first language transfer as one of the primary sources of L2 divergence for request strategies and modification devices (Barron, 2003, 2007; Li, 2014; Schauer, 2009, Author, 2011, 2014). Specifically regarding L2 English users from Chinese backgrounds, empirical investigations have identified the following common interlanguage features of requests, influenced by the L1: (internal modification) overuse of downgraders 'can/could' (Lin, 2009; Rose, 2000; Yu, 1999), general underuse of internal modification devices (Fukushima, 2002; Yu, 1999); (external modification) use of multiple apologies to signal politeness (Yu, 1999; Zhang, 1995), general overuse of external modification devices (Wang, 2011; Yu, 1999; Zhang, 1995). An additional feature showing overuse of a because-therefore pattern of information sequencing whereby the reason precedes the request, is also common with Chinese learners of English (Chen, 2015; Kirkpatrick, 1991, 1992; Wang, 2011;Yu, 1999). What links many of these studies is that the 
data demonstrate variability amongst study group participants, often neglecting to examine the influence of affective factors such as motivation on L2 pragmatic development (Takahashi, 2012 is an exception), and therefore highlighting the complexities of measuring pragmatic performance in the host environment.

\subsection{Instructional interventions in the SA context}

Given empirical evidence often reports variability in pragmatic gains during the SA period, metapragmatic instructional intervention may benefit learners, particularly if undertaking a short-term SA sojourn. To date, despite calls outlining instructional benefits (Jeon and Kaya, 2006; Taguchi, 2014; 2015), this area of SA investigations is limited to a small collection of studies examining the benefits of instruction and effects of SA within the host environment (Alcon Soler, 2015; Shively, 2011; Winke and Teng, 2010). In addition, to the authors' knowledge, only one study has examined the effects of pre-departure instruction on request language (Cohen and Shively, 2007). Overall, despite a range of quantitative and qualitative measures, within different L2 contexts (China, France, Spain, UK), over a range of time periods (eight weeks to one academic year), these SA investigations show pedagogical intervention to be successful in improving pragmatic performance across a number of areas: advancing pragmalinguistic choices (Alcon Soler, 2015; Cohen and Shively, 2007; Winke and Teng, 2010), enhancing metapragmatic awareness (Henery, 2015), furthering cross cultural understanding (Winke and Teng, 2010), and building confidence to deal with conflicting L1/L2 norms (Shively, 2011).

Cohen and Shively (2007) has a number of similarities to the present investigation. Tracking 86, mostly American, learners' semester-long SA sojourns in France and Spain, the study aimed to examine the effectiveness of pre-departure and in-country pragmatic interventions on request and apology language, compared to a non-participatory control 
group. The interventions comprised a two-hour pre-departure instruction and orientation on language and culture with some speech act focus, in addition to phased self study material and reflective e-journal entries during the SA period, as employed in other studies (Shively, 2011; Winke and Teng, 2010). From an acquisitional perspective, the findings indicated that the four-month exposure had been instrumental in the significant pre-test to post-test gains achieved in both request and apology language for both the experimental and control groups. From an instructional perspective, however, despite the six French and Spanish NS raters' awarding the instructed group higher scores for their responses on a 10-item written production task showing some instructional effect, this was not statistically significant. The authors concluded that the intervention was not intensive, effective, or focussed enough in terms of content to be beneficial.

\subsection{Research gaps}

The data from the aforementioned studies indicate that instruction alongisde L2 exposure is in general advantageous in developing L2 pragmatic competence but also highlights some methodological issues which may have affected results. First, data collection instruments such as written production tasks (Cohen and Shively, 2007) are known to generate responses which show what participants perceive they might say instead of what they might actually say in a given siutation (Golato, 2003). Second, forms of data collection such as recordings from natural interactions (Shively, 2011) do not offer controlled conditions where sociolinguistic variables of interlocutors can be managed. Eliciting oral data, does not allow for capturing all features of natural spoken data such as interactivity. However, the length and content of responses captured from oral role plays (on which the CAPT instrument is based) have been found to mirror authentic spoken discourse more closely than written data and that is one of the clear advantages of employing this tool over written tools (Author, 2013). Third, comparability of particpant groups is also a limitation in several of these 
studies. In Alcon Soler's (2015) study, the participants had different motivations for learning (work or study), Cohen and Shively’s (2007) participants groups came from a variety of academic majors and were enrolled on a variety of study abroad programmes, and Winke and Teng's (2010) sample experienced shorter and longer pre-departure instructional periods which may have affected results. Finally, where pragmatic input is presented as a self study package whilst in-country, raises potential issues with learner effort and motivation to engage in the material, as noted by Cohen and Shively (2007). The latter issues, in particular, point to a need to examine the efficacy of pre departure interventions which specifically target the pragmatic features under investigation, and where performance amongst comparable groups can be measured under controlled conditions. These issues are directly addressed in the present study.

From a design perspective, to the best of our knowledge, no other research has examined the effects of an explicit, classroom-based pre-departure intervention with Chinese ESL learners attending a UK-based SA programme. The aim is to extend the limited current literature which examines pragmatic instruction and study abroad effects and in doing so, we are seeking to answer the following research questions:

RQ1 To what extent does explicit pragmatic instruction of spoken requests in a pre-departure intervention impact on the development of successful requests immediately following instruction and after six months of study abroad?

RQ2 To what extent can changes in internal and external modification of requests be observed immediately following instruction and after six months of study abroad? 


\section{Methodology}

\subsection{Participants}

Thirty four learners (twelve male, twenty two female) were randomly assigned to two treatment groups: experimental group $(n=17)$, and control group $(n=17)$. All learners were of Chinese nationality (Mandarin speakers) and the mean age was 22 for the experimental group and 21.9 for the control group (age range of both groups 20-23 years). The mean amount of prior English learning was 7.6 years (experimental group) and 7.5 years (control group) with a range of seven to nine years of English study. All students were about to undertake one academic year of an undergraduate course in International Business Communication in the UK. As part of their course, students received English language instruction in China prior to departure for the UK to begin the final year of their programme. At the end of instuction in China, participants were required to successfully complete a standardised test and were all rated at CEFR B2 level for reading, writing, speaking and listening. A learner's competency at this level can be broadly defined as someone who 'can interact with a degree of fluency and spontaneity that makes regular interaction with native speakers quite possible without strain for either party' (Council of Europe, 2001, p.24). As only learners of the same nationality, on the same course and at the same level were chosen for this study, this was a homegenous sample, as defined by Dornyei (2007, p. 127) because the intention was to investigate two groups with similar characteristics. The present study delivered the instruction and administered the pre-test and immediate post-tests in China, using the UK host environment to measure long term recall (experimental group) and implicit learning (control group) of request language. The study was conducted over six months and and concluded half way through the study abroad year. Participants who met the criteria above volunteered to take part in the study. 


\subsection{Study design}

This study employed an experimental design often used in this type of research (Cohen, Mannion and Morrison, 2007, p.275) because it compared two groups of learners at the same proficiency level, and used pre-, post-and delayed tests to measure immediate gains and gains made over time. The tests took place a week prior to the treatment, immediately after treatment (while all learners were in China) and then after a delay of six months, in the UK. Although there is no exact consensus about the ideal time to employ a delayed test in a study of this kind, it has been suggested that a delay of more than a week is optimal and three weeks or longer ideal (Schmitt, 2010, p.157). As we wished to investigate the impact of instruction prior to departure for the UK and the long term effect of this instruction while in the SA environment, a delay of six months after instruction was considered sufficient to test long term acquisition.

The tests used to elicit data were based on a six-scenario oral computer-animated production test (CAPT) of the type described by Author (2013), modified for requests. These tests use an animated figure within virtual role plays to provide learners with a context and spoken prompt to which they respond and record their answers. For example, one situation could be 'You are in the university and want to reseve a book. Listen to the librarian and then speak. The librarian then says ' Hello, how can I help?' To avoid participants' memorising answers, the order and wording of items and tasks was amended for each version of the tests, a sample of which can be found in Appendix A. This method of data collection addresses some of the well-documented drawbacks of traditional written DCTs such as authenticity of interaction and learner response. For instance, the computer-animated characters are able to display a range of non-verbal signals such as facial expressions and gestures, considered to be as powerful as verbal cues (Wik and Hjalmarsson, 2009; Yang and Zapata-Rivera, 2010). Secondly, authentic voice recordings can be uploaded for the characters, which also aim to 
simulate semi-authentic interaction in the academic environment. Author (2013) reports the CAPT successfully eliciting language which is closer to what students would actually say in a given situation, rather than what they might say, when compared to written DCTs. For instance, Author found written DCT responses tended to be longer, and often included extraneous detail, unlike the more efficient CAPT responses, as these examples, from the same participant, illustrate;

(lost book borrowed from tutor scenario):

Sorry, sir. I am made a big mistake that I lost a book that you lent me. I try my best to find where it is but I can't and I try and find a new one but I don't know where I can buy it. I'm really sorry about that. Can you tell me where I can buy this book? I will buy a new one for you. I very apologise about that. (Written production task response).

I apologise about that. Last week you lent me a book but now I can't find it at home. I'm so sorry. Can I buy you a new one? (CAPT response).

These virtual role plays were selected over face-to-face role plays for efficiency of being able to administer all the tests simultaneously, under controlled conditions. All of the scenarios and characters were designed to be familiar to learners studying in an academic SA context. The interlocutors within the CAPT were characters who the learners were likely to encounter on campus (e.g. a tutor, a librarian, a campus security guard), thereby increasing the external face validity of the instrument (Nureddeen, 2008). Higher imposition requests were included in the scenarios, as led by staff members' descriptions of situations typifying interactions with international students, elicited during the design of the test e.g. requesting an extension for an assignment from a tutor; requesting a book loan beyond the permitted period; asking a campus security guard to retrieve a mobile phone from a classroom out of hours. 
Participants were therefore placed in familiar roles and situations, according to the academic context within which they were currently studying, which are said to be key considerations to improve both the quality of response and construct validity of the tests (Bardovi-Harlig, 1999; Schauer, 2007).

\subsection{Instructional treatment}

The treatment itself consisted of five hours of classes on requests for the experimenatal group only, spread over three weeks. These students received explicit instruction from two trained tutors on the pragmalinguistics aspects of spoken requests whilst in China. The procedure was designed to raise students' awareness of the pragmatic appropriacy of particular request forms, the language required to formulate them, and to give learners practice in producing appropriate requests in specific academic scenarios. For the purposes of this study, 'appropriateness' was defined as 'the knowledge of the conventions of communication in a society, as well as linguistic abilities that enable learners to communicate successfully in L2.' (Taguchi, 2006, p.513). To aid this process, all sessions contained equal amounts of the following three stages (though not always in this order): 1) cross-cultural analysis and discussion of the appropriacy of sample requests used in academic scenarios of both high and low social distance. The concepts of high and low social distance, degree of impostion and power were all given explicit treatment, 2) language focus clarification of request organisation and typical lexical chunks used in request head acts and internal/external modification were taught, 3) pre-communicative and communicative practice, such as drilling and roleplays in various scenarios was undertaken. These stages broadly follow Uso-Juan's (2010) stages of awareness-raising and communicative practice activities; aspects of explicit instruction considered requisite for success (Bardovi-Harlig, 2001). Promoting real-world learning (in terms of working with familiar scenarios and 
contexts), and self reflection strategies (evaluating current pragmatic practices and interlanguage gaps), as advocated by Shively (2010), also featured in the instruction. The treatment type was explicit, in the sense that 'the learner is aware of what has been learned' (Richards and Schmidt, 2002, p.250) because both form and meaning were clearly highlighted. This was because, as highlighted above, it is explicit teaching which has in general beeen found to be more effective within instructed SLA studies (Norris and Ortega, 2000; Taguchi, 2014; 2015) and has also proved effective in interlanguage pragmatics research (Eslami and Eslami-Rasekh, 2008; Author, 2011; Safont, 2004). The duration of the instruction was selected on the basis of Jeon and Kaya's (2006) meta-analysis of instructional pragmatic studies which suggested five hours of instruction or more produces more beneficial results. The control group received no instruction on spoken requests but continued to receive general English instruction as part of their programme.

\subsection{Data analysis}

\subsubsection{Rater analysis}

The data were analysed using SPSS. First, recordings of the oral test were transcribed and then rated by two English language teachers not related to the study. Each response was rated on a holistic scale from 1-5, with raters reading the scenario and judging the level of appropriacy of each request made; with (1) being innapropriate and (5) being completely appropriate, based on the definition of appropriateness given previously. The raters were unaware of the instructed versus uninstructed test design but participated in some brief training for standardisation purposes. The raters' scores were compared using the Pearson correlation coefficient and were found to have high interater reliabaility (pretest $=.75$; posttest $=.88$; delayed test $=.79)$. The raters' scores were also subject to a series of SPSS measures. Initial histogram checks confirmed both sets of data were normally distributed. 
Subsequent analyses consisted of repeated measures ANOVAs to test the effectiveness of the treatment on each group, and independent and paired samples t-tests then compared the gains made by each group on each test. Effect size measures were also included in the analysis.

\subsubsection{Linguistic analysis}

Our final examination analysed the frequency of internal and external modification of the requests at pre-test, post-test and delayed tests stages for both groups. Following completion of the tests, all samples were transcibed. The data were then analysed in order to count the frequency of internal modification and external modification in each scenario by each group. This analysis was based on categories suggested by Blum-Kulka, House and Kasper (1989) and adapted by Halupka-Rešetar (2014) as shown in Table 1.

Table 1

Internal and external modification categories

\begin{tabular}{ll}
\hline Internal modification catergories & External Modification catergories
\end{tabular}

\begin{tabular}{ll}
\hline Please & Grounders (because + explanation \\
$\begin{array}{ll}\text { Downtowners (possibly/maybe) } \\
\text { fedges (a bit/sort of/kind of) }\end{array}$ & $\begin{array}{l}\text { Preparators (Pre-request explanation } \\
\text { Downgraders (Can /could /would /I }\end{array}$ \\
such as 'I have some problems') \\
was wondering) & Promises (I promise/I will) \\
Subjectivisers (I'm afraid/I wonder) & Apologies (Sorry/expressions with \\
& corry) \\
& Alerters (Excuse me) \\
\hline
\end{tabular}


The data were searched for examples and then each was examined manually to ensure the use fitted the function given. For example, 'I will' was only counted if it was used as a form of promise and not as a prediction. It was felt that adding this dimension would be instructive when viewed alongside raters' scores as it allowed us to examine the effect of instruction and lack of instruction on the language and organisation of each groups' requests. These scores were also subject to repeated measures ANOVAs and independent samples ttests to compare the frequency and effect of each type of modification.

\section{Results and discussion}

RQ1 To what extent does explicit pragmatic instruction of spoken requests impact on the development of successful requests immediately following instruction and after six months of a study abroad period?

Table 2 gives the means and standard deviations of the raters' scores for each group, at each stage of the study. Standard deviations are displayed in brackets.

Table 2

Descriptive statistics: Effects of instruction

\begin{tabular}{lccc}
\hline & Pre & Post & Delayed \\
\hline \multicolumn{1}{c}{ Group } & $\mathrm{M}(\mathrm{SD})$ & $\mathrm{M}(\mathrm{SD})$ & $\mathrm{M}(\mathrm{SD})$ \\
\hline Exp $(\mathrm{N}=17)$ & $25.53(8.76)$ & $43.47(8.15)$ & $36.29(8.08)$ \\
Control $(\mathrm{N}=17)$ & $31.59(11.01)$ & $31.82(9.63)$ & $39.29(8.72)$ \\
\hline Total $(\mathrm{N}=34)$ & $28.56(10.27)$ & $37.65(10.59)$ & $37.79(8.42)$ \\
\hline Note. & & \\
Maximum score $=60(6$ scenarios x max 5 points x 2 raters)
\end{tabular}


These mean scores show an improvement over time for both groups, according to the raters' assessments, with a stronger improvement following instruction for the experimental group. A 3 (time) $\times 2$ (group) repeated measures analysis of variance (ANOVA) confirms the mean differences. In terms of instructional effects, there was a significant main effect of time; $F(2,64)=25.89, p<.001, \eta_{p}^{2}=.45$, and interaction between time and group; $F(2,64)=$ 20.72, $p<.001, \eta_{p}^{2}=.39$. No significant effect was found for group; $\mathrm{F}(1,32)=.108, p=.744$, $\eta_{p}^{2}=.003$

The interaction effects show there were differences in how the two groups performed over time. Within groups t-tests revealed significance at several stages. The experimental group showed a significant improvement at the pre-test to post-test stage $(p=.001)$ and significant attrition at the post-test to delayed test stages $(p=.015)$. This shows, as we might expect, an immediate effect of the treatment, which decreased significantly over time, while remaining higher than it was at the pre-test stage, and was in fact significant when we compare pre-test to delayed test scores $(p<.001)$. For the control group there was also significant improvement at the post-test to delayed test $(p=.011)$ stage and significant improvement at the pre-test to delayed test stage $(p=.003)$. This suggests that the SA environment had a positive impact for both groups, to some degree. Both groups improved their scores significantly in terms of pre-test to delayed test gains but only the control group improved their post-test to delayed test scores. Measures of effect sizes show that largest effect was found for the experimental group when looking at the gains in their pre-test to post-test score $(d=2.915)$ and the gains made at the pre-test to delayed test stages were also shown to have a large effect $(d=1.124)$. However, the attrition at the post-test to delayed test stage for the experimental group was also shown to have a large effect $(d=0.964)$. For the control group, the gain shown at the pre-test to delayed test stage was shown to have a large effect $(d=$ 
0.880 ) and the improvement at the post-test to delayed test stage, a medium size effect ( $d=$ $0.697)$.

Independent samples t-tests of the total scores for each group were used to compare the raters' scores at each stage. Results revealed that in comparisons between the groups, the only significant difference was found at the post-test stage, where the experimental group's score was significantly better $(p=.001)$. This suggests that the instruction was more effective in this study in the short term only and this is confirmed by the fact that this difference was shown to have a large effect at this stage $(d=1.31)$. Such a finding is consistent with other studies in this area (Alcon Soler, 2015; Author, 2011), which often demonstrate intial benefits of treatment, followed by some atttition of these intial gains. Examples of improved request forms (from pre-test to post-test) from one scenario can be found in Appendix B.

\section{RQ2 To what extent can changes in internal and external modification of requests be observed immediately following instruction and after six months of a study abroad period?}

Tables three and four show the means and standard deviations for the experimental and control groups in relation to their frequency of total use of internal and external modification devices in each scenario, at each test stage.

Table 3

Descriptive statistics: Total frequency of internal modification

\begin{tabular}{cccc}
\hline & Pre & Post & Delayed \\
\hline Group & M (SD) & M (SD) & M (SD) \\
\hline
\end{tabular}




\begin{tabular}{llll}
\hline $\operatorname{Exp}(\mathrm{N}=17)$ & $4.05(.96)$ & $8.29(1.64)$ & $6.52(1.06)$ \\
Control $(\mathrm{N}=17)$ & $4.52(1.58)$ & $5.35(2.57)$ & $9.23(3.54)$ \\
\hline Total $(\mathrm{N}=34)$ & $4.29(1.31)$ & $6.82(2.59)$ & $7.88(2.92)$ \\
\hline
\end{tabular}

Note.

There was no minimum or maximum score

Table 4

Descriptive statistics: Total frequency of external modification

\begin{tabular}{lccc}
\hline & Pre & Post & Delayed \\
\hline \multicolumn{1}{c}{ Group } & $\mathrm{M}(\mathrm{SD})$ & $\mathrm{M}(\mathrm{SD})$ & $\mathrm{M}(\mathrm{SD})$ \\
\hline Exp (N=17) & $7.00(1.41)$ & $13.29(.77)$ & $8.00(1.80)$ \\
Control (N=17) & $7.00(1.83)$ & $7.64(1.45)$ & $12.29(1.40)$ \\
\hline Total $(\mathrm{N}=34)$ & $7.00(1.61)$ & $10.47(3.08)$ & $10.14(2.72)$ \\
\hline Note. & & & \\
\end{tabular}

There was no minimum or maximum score

A 3 (time) x2 (group) repeated measures ANOVA reveal significant effects of instruction over time for both internal and external modification devices, with large effect sizes; (internal modification) $F(2,64)=65.63, p<.001, \eta_{p}^{2}=.67 ;$ (external modification) $F(2,64)=157.49, p<.001, \eta_{p}^{2}=.83$. Significant effects were also observed for time $\mathrm{x}$ group with large effect sizes; (internal modification) $F(2,64)=39.04, p<.001, \eta_{p}^{2}=.55$; (external modification) $F(2,64)=266.29, p<.001, \eta_{p}^{2}=.89$, but no significance was found for group; (internal modification) $F(1,32)=.016, p=.90, \eta_{p}^{2}=.001 ;($ external modification) $F(1,32)=$ $.99, p=.32, \eta_{p}^{2}=.03$. 
The interaction effects show there were differences in how the two groups also used external and internal modification over time. Independent samples t-tests of the total scores for each group were used to make comparisons at each stage. Results revealed that in comparisons between the groups, there were significant differences for use of internal modification, with the experimental group using significantly more internal modifiers at the post-test stage $(p<$ $.001, d=1.393)$ and the control group using significantly more at the delayed test stage $(p=$ $.005, d=1.172)$. There was a large effect in each case. These results mirror other reported findings which suggest initial underuse pre-instruction (Schauer, 2007, 2009; Li, 2014; Woodfield, 2008, 2012; Woodfield \& Economidou-Kogetsidis, 2010) with a move towards more target-like levels, post-instruction (Alcon Soler, 2015; Cohen and Shively, 2007).

There was a similar pattern for external modification, at the post-test and delayed test stages. At the post-test stage, the experimental group used significantly more external modification with a large effect size $(p<.001, d=5.072)$. At the delayed-test stage, the control group used significantly more external modification, with a large effect size $(p<.001$, $d=2.6208$ ). Contrary to previous findings (Wang, 2011; Yu, 1999; Zhang, 1995), these results suggest no evidence of overuse of external modification pre-instruction but a shift towards L2 norms, as observed with internal modifiers.

Overall, these results show, as the analysis for research question one did, that higher ratings for the experimental group resulted from significantly more use of internal and external request modification at the post-test stage, and that instruction has been beneficial for supporting learners' production of pragmatic features seen to be challenging from an acquisitional perspective, when targeted input is not available (Schauer, 2007, 2009; Li, 2014; Woodfield, 2008, 2012; Woodfield and Economidou-Kogetsidis, 2010). In line with Alcon Soler's (2015) intervention study, this difference was not sustained into the delayed-test stage. 
It also shows that greater use of external or internal modification was not always linked to greater ratings of appropriacy post-instruction, as the results for research question one show that there were no significant differences in the ratings for the requests of either group at the delayed test stage, as also reported by Alcon Soler (2015).

This indicates that it is not only the amount of modification which makes requests more successful but also how the modification is chosen for a particular scenario and also, as discussed elsewhere (e.g. Author, 2014), how the requests are organised. An analysis of the types of modifications used by both groups gives evidence of this. Tables five and six show the types of modification most commonly used by each groups at each test stage, as revealed by searching the data and manually checking each use matched the function given. Each table gives the number of times this category was used, and the percentage of the total modification type, per group, that this represents.

Table 5

Most frequent form of internal modification

\begin{tabular}{llll}
\hline & Pre & Post & Delayed \\
\hline Group & Freq. (\%) & Freq. (\%) & Freq. (\%) \\
\hline \multirow{2}{*}{ Exp (N=17) } & Downgraders & Downgraders & Downgraders \\
& $67,(97.1 \%)$ & $79,(54.4 \%)$ & $94,(86.2 \%)$ \\
& Downgraders & Downgraders & Downgraders \\
Control $(\mathrm{N}=17)$ & $63,(81.8 \%)$ & $73,(78.4 \%)$ & $124,(77.9 \%)$ \\
& & & \\
\hline
\end{tabular}


Note.

Freq. $=$ frequency of use

$\%=$ percentage of all possible internal modifiers

Table 6

Most frequent form of external modification

\begin{tabular}{lcll}
\hline & Pre & Post & Delayed \\
\hline Group & Freq. (\%) & Freq. (\%) & Freq. (\%) \\
\hline Exp (N=17) & Preparator & Apology & Preparator \\
& $60,(50.4 \%)$ & $83,(37.2 \%)$ & $50,(36.7 \%)$ \\
& Preparator & Preparator & Preparator \\
Control (N=17) & $59,(49.1 \%)$ & $60,(46.1 \%)$ & $92,(44 \%)$ \\
& & & \\
Note. & & \\
Freq.= frequency of use & \\
\end{tabular}

These results give us some evidence that instruction had a positive effect on the language students used in requests. Beginning with internal modification, it is clear that downgraders were the most common form used by both groups, in terms of frequency of use. However, the lower percentage at the post-test stage shows that the experimental group used a greater range of language, selecting alternative mitigators, for the purposes of internal modification. A closer examination of the types of downgraders at this post-test stage also shows that the experimental group were able to make use of a wider range of these in a way which was sensitive to each context. These uses are displayed in Table seven below. 
Table 7

Most common forms used as downgraders

\begin{tabular}{|c|c|c|c|}
\hline & Pre-test & Post-test & Delayed \\
\hline Group & Freq. $(\%)$ & Freq. $(\%)$ & Freq. $(\%)$ \\
\hline EXP & Can $=54(80.5 \%)$ & Can $=8(10.1 \%)$ & Can $=31(32.9 \%)$ \\
\hline \multirow[t]{3}{*}{$(\mathrm{N}=17)$} & Could $=9(13.4 \%)$ & Could $=30(37.9 \%)$ & Could $=52(55.3 \%)$ \\
\hline & Would $=4(5.9 \%)$ & Would $=30(37.9 \%)$ & Would $=10(10.6 \%)$ \\
\hline & I was wondering $=0$ & I was wondering $=11(13.9 \%)$ & I was wondering $=1(1.06 \%)$ \\
\hline Control & $\mathrm{Can}=40(63.4 \%)$ & $\mathrm{Can}=51(69.8 \%)$ & $\mathrm{Can}=75(60.4 \%)$ \\
\hline \multirow[t]{3}{*}{$(\mathrm{N}=17)$} & Could $=22(34.9 \%)$ & Could $=19(26 . \%)$ & Could $=45(36.2 \%)$ \\
\hline & Would =1 (1.5\%) & Would $=3(4.1 \%)$ & Would $=4(3.2 \%)$ \\
\hline & I was wondering $=0$ & I was wondering $=0$ & I was wondering $=0$ \\
\hline
\end{tabular}

Note.

Freq. $=$ frequency of use.

$\%=$ frequency of use as a percentage of all downgraders

This data shows that at each stage, the control group relied heavily on 'can', with little or no use of other request sequences, and that the experimental group used a broader range of request forms. At the post-test stage, for example, 'can' was only used in ten percent of the requests made by the experimental group, and 'could' and 'would' (from sequences such as 'Would you mind', 'Would it be possible to') made up over seventy five percent of the total usage. In addition, we also see the introduction of 'I was wondering if' with the experimental group. At the same stage, 'can' accounted for almost seventy percent of the forms used by the control group. For the control group, this suggests the influence of L1 transfer and the common overreliance on a limited range of downgraders, as noted in other investigations 
(Lin, 2009; Rose, 2000; Yu, 1999). In contrast, the instruction has helped the experimental group to expand their repertoire of formulaic request sequences, and sensitise students to the need to use downgraders as appropriate for each context, and this is also reflected to a lesser degree in the post-test usage of both groups. The examples below show the forms being used at the post-test stage and are from scenario one (asking to book a study room in the library).

Experimental group

I'm really I'm really sorry to bother you er I was wondering if you can tell me how to book a study room thank you very much

Control group

Excuse me I want I want to find a study book er I find out er can you help me

In terms of external modification, the greater use of 'apology' as an external modifier at the post-test stage for the experimental group, demonstrates to some degree that the instruction developed sensitivity to the imposition of the request in particular scenarios with higher status interlocutors. At this stage, the control group, on the other hand, continued to rely heavily on preparatory statements prior to the request and were not always as sensitive to the appropriate language needed when there was likely to be some imposition on the listener. The two samples below, from scenario six (asking your tutor for some handouts after you have missed a class) show some evidence of this.

Experimental group

Excuse me er sorry to bother you erm I was wondering if er if you if you give me the er worksheets

Control group 
Sir I have a problems to ask you for help could you please give me the wor... worksheets from you I very I really need it thank you

The examples above also show that the experimental group were better able to use an apology, alongside what would often be the expected moves of the request. In this example, we can see the use of a pattern which can be described as 'alerter + apology + polite request form' by the experimental group while the control group uses 'polite address form + statement of problem + polite request form + reason'. While both have been rated equally in terms of appropriacy, we would argue here that the experimental group's request is more closely aligned with the moves we would expect in this scenario, where there is a certain power differential and social distance between the speakers and some imposition caused by the request. Appropriate organisation of request moves has been shown to be a key feature of successful learner requests (Author, 2014). The use of preparators by both groups at the pretest and delayed test stages also shows that without regular instruction, Chinese learners may fall back on their L1 norms and rely on this as a request strategy. Chen (2015), Kirkpatrick (1991, 1992), Wang, (2011), and Yu (1999) highlight that pre-request moves are a common politeness device amongst Chinese L1 speakers.

\section{Conclusion}

This study aimed to investigate explicit instructional effects of requests, and the relationship between post-treatment language production and L2 contact. Overall, the results indicate that explicit teaching of spoken requests does have a significant immediate effect. This clearly shows the benefit of instruction in the short term. Whilst the attrition in delayed test scores is disappointing, it does demonstrate the need for regular repeated instruction, with practice distributed over time, something which it has been suggested (e.g. Rohrer, 2015) can 
have a more positive impact upon acquisition than practice given intensively within a short time period. The study also demonstrates that the instruction has a clear impact upon the use of external and internal modification of requests. In the short term, this resulted in significantly higher amounts of this modification for the experimental group and at the delayed test stage, this was reversed. However, investigation of the language used to formulate requests also demonstrated that the experimental groups expanded their repertoire of request forms and showed more sensitivity towards the imposition of the request on the speaker in their choice of language used to offer apology and to downgrade requests. The control group, on the other hand, experimented with these forms of internal and external modification much less and tended to rely on organisation patterns from L1 a great deal. Taken together, the results demonstrate the need to analyse appropriacy of request forms both holistically and in combination with a more fine-grained analysis of the types of modification learners use. Overall, it is our view pragmatic instruction should be initiated at the predeparture stage in order to raise pragmatic awareness so learners are able to make early crosscultural connections. Once in-country, learners are often initially preoccupied with orientation activities and can be overwhelmed with study abroad induction information. Revisiting those early pre-departure connections in the classroom, through frameworks such as Shively (2010) and Uso-Juan (2010), could facilitate the noticing and self-reflection processes, in addition to saliency of the pragmatic input. Further, this study has shown pragmatic instruction needs repeated attention in the host environment for long term recall.

As this study shows that intensive pre-departure instruction had a strong effect in the short term, future research could address these findings by contrasting the effects of instruction which provides intensive and distributed practice with speech acts such as requests, or other speech acts, and over extended time periods. Such studies could usefully explore the appropriacy of requests and the short and long term effects of metapragmatic 
instruction on the request forms used by participants. Research of this kind could be combined with qualitative data in order to explore students' English contact in the SA environment in more detail. Specifically, affective factors such as motivation and learner beliefs are rarely investigated in studies such as these and this would be an interesting dimension to consider amongst different international groups. Finally, it is hoped this study encourages further investigation into the benefits of pre-departure SA preparation programmes, given the paucity of current pragmatic studies in this area.

\section{References}

Al-Gahtani, S., \& Roever, C. (2013). "Hi doctor, give me handouts": Low-proficiency learners and requests. ELT Journal, 67(4), 413-424. doi:10.1093/elt/cct036

Alcón-Soler, E. (2015). Pragmatic learning and study abroad: Effects of instruction and length of stay. System, 48, 62-74. doi:10.1016/j.system.2014.09.005

Author (2011)

Author (2013)

Author (2014)

Bardovi-Harlig, K. (1999). Exploring the Interlanguage of Interlanguage Pragmatics: A research agenda for Acquisitional Pragmatics. Language Learning, 49(4), 677-713. doi:10.1111/0023-8333.00105

Bardovi-Harlig, K. (2001). Evaluating the emprical evidence: grounds for instruction in pragmatics. In K. R. Rose \& G. Kasper (Eds.), Pragmatics in Language Teaching (pp. 13-32). Cambridge: Cambridge University Press.

Bardovi-Harlig, K. (2013). Developing L2 Pragmatics. Language Learning, 63, 68-86. doi:10.1111/j.1467-9922.2012.00738.x 
Bardovi-Harlig, K., \& Bastos, M.-T. (2011). Proficiency, length of stay, and intensity of interaction and the acquisition of conventional expressions in L2 pragmatics. Intercultural Pragmatics, 8(3), 347-384. doi:10.1515/iprg.2011.017

Barron, A. (2003). Second language acquisition in a study abroad context. Amsterdam: Benjamins.

Barron, A. (2007). “Ah no honestly we're okay:” learning to upgrade in a study abroad context. Intercultural Pragmatics, 4(2), 129-166. doi:10.1515/ip.2007.009

Bataller, R. (2010). Making a request for a service in Spanish: Pragmatic development in the study abroad setting. Foreign Language Annals, 43(1), 160-175. doi:10.1111/j.19449720.2010.01065.x

Bella, S. (2011). Mitigation and politeness in Greek invitation refusals: Effects of length of residence in the target community and intensity of interaction on non-native speakers' performance. Journal of Pragmatics, 43(6), 1718-1740.

doi:10.1016/j.pragma.2010.11.005

Beltrán, E. (2014). Length of stay abroad: Effects of time on the speech act of requesting. International Journal of English Studies, 14(1), 79-96. doi:10.6018/ijes/14/1/155211

Blum-Kulka, S., House, J., \& Kasper, G. (1989). Cross-cultural Pragmatics: Requests and apologies. Norwood, NJ: Ablex Pub. Corp.

Chen, Y. (2015). Developing Chinese EFL learners' email literacy through requests to faculty. Journal of Pragmatics, 75, 131-149. doi:10.1016/j.pragma.2014.05.009

Code, S. \& Anderson, A. (2001). Requests by young Japanese: A longitudinal study. The Language Teacher Online, 25 (8). Retrieved from: http://www.jaltpublications.org/tlt/articles/2001/08/anderson/

Cohen, L., Manion, L., Morrison, K., \& Cohen, P. L. (2007). Research methods in education (6th ed.). London: Routledge. 
Cohen, A. D., \& Shively, R. L. (2007). Acquisition of requests and apologies in Spanish and French: Impact of study abroad and strategy-building intervention. The Modern Language Journal, 91(2), 189-212. doi:10.1111/j.1540-4781.2007.00540.x

Council of Europe (2001). Common European framework of reference for languages: Learning, teaching, assessment. Cambridge, U.K.: Cambridge University Press.

Dörnyei, Z. (2007). Research methods in applied linguistics: Quantitative, qualitative, and mixed methodologies. Oxford: Oxford University Press.

Ellis. R. (1992). Learning to communicate in the classroom: a study of two learners' requests, Studies in Second Language Acquisition, 14 (1), 1-23

Eslami, Z. R., \& Eslami-Rasekh, A. (2008). Enhancing the Pragmatic Competence of Nonnative English-speaking Teacher Candidates (NNESTCs) in an EFL context. In E. A. Soler (Ed.), Learning how to request in an instructed language learning context (pp. 178197). Switzerland: Peter Lang Pub.

Félix-Brasdefer, J. C. (2004). Interlanguage Refusals: Linguistic politeness and length of residence in the target community. Language Learning, 54(4), 587-653. doi:10.1111/j.1467-9922.2004.00281.x

Félix-Brasdefer, J. C. (2007). Pragmatic development in the Spanish as a FL classroom: A cross-sectional study of learner requests. Intercultural Pragmatics, 4(2), 253-286. doi:10.1515/ip.2007.013

Fukushima, S. (2002). Requests and culture: Politeness in British English and Japanese. Switzerland: Peter Lang AG.

Golato, A. (2003). Studying compliment responses: A comparison of DCTs and recordings of naturally occurring talk. Applied Linguistics, 24(1), 90-121. doi:10.1093/applin/24.1.90

Halupka-Rešetar, S. (2014). Request modification in the pragmatic production of intermediate ESP learners. ESP Today, 2 (1), 29 -47. 
Henery, A. (2015). On the development of metapragmatic awareness abroad: two case studies exploring the role of expert-mediation. Language Awarness, 24(4), 316-331

Hill, T. (1997). The development of pragmatic competence in an EFL context. Unpublished doctoral dissertation, Temple University, Tokyo.

Iwasaki, N. (2010). Style shifts among Japanese learners before and after study abroad in Japan: becoming active social agents in Japanese. Applied Linguistics, 31, 45-71

Jeon, A. H., \& Kaya, T. (2006). Effects of L2 instruction on interlanguage pragmatic development. In J. M. Norris \& L. Ortega (Eds.), Synthesizing research on language learning and teaching (pp. 165-211). Amsterdam: John Benjamins Publishing Co.

Kasper, G., \& Rose, K. R. (2002). Pragmatic development in a Second language. Malden, MA: Blackwell Publishers.

Kinginger. C. (2008). Language learning in study abroad: Case studies of Americans in France. The Modern Language Journal, 92 (supplement), iii-131

Kinginger, C. (2013). Social and Cultural Aspects of Language Learning in Study Abroad. Amsterdam: John Benjamins.

Kinginger. C. \& Farrell, K. (2004). Assessing development of meta-pragmatic awareness in study abroad. Frontiers: The Interdisciplianry Journal of Study Abroad, 10, 19-42

Kirkpatrick, A. (1991). Information sequencing in Mandarin letters of request. Anthropological Linguistics, 33(2), 183-203

Kirkpatrick, A. (1992). Schemas, authentic texts and cross-cultural communication. Australian Review of Applied Linguistics supplement 9, 101-119

Li, S. (2014). The effects of different levels of linguistic proficiency on the development of L2 Chinese request production during study abroad. System, 45, 103-116 doi:10.1016/j.system.2014.05.001 
Lin, Y.-H. (2009). Query preparatory modals: Cross-linguistic and cross-situational variations in request modification. Journal of Pragmatics, 41(8), 1636-1656. doi:10.1016/j.pragma.2008.12.007

Norris, J. M., \& Ortega, L. (2000). Effectiveness of L2 instruction: A research synthesis and quantitative Meta-analysis. Language Learning, 50(3), 417-528. doi:10.1111/00238333.00136

Nureddeen, F. A. (2008). Cross cultural pragmatics: Apology strategies in Sudanese arabic. Journal of Pragmatics, 40(2), 279-306. doi:10.1016/j.pragma.2007.11.001

Octu, B., \& Zeyrek, D. (2008). Development of requests: A study on Turkish learners of English. In M. Puetz \& J. Neff van Aertselaer (Eds.), Developing Contrastive Pragmatics: Interlanguage and Cross-cultural Perspectives (pp. 265-300). Berlin: Mouton de Gruyter.

Paige, R. M., Cohen, A. D., \& Shively, R. (2004). Assessing the impact of a strategies-based curriculum on language and culture learning abroad. Frontiers: The Interdisciplinary Journal of Study Abroad, 10, 253-276.

Ranta, L., \& Meckelborg, A. (2013). How much exposure to English do international graduate students really get? Measuring language use in a naturalistic setting. Canadian Modern Language Review, 69(1), 1-33. doi:10.3138/cmlr.987

Richards, J. C., \& Schmidt, R. (2002). Longman dictionary of language teaching and applied linguistics (3rd ed.). New York: Longman.

Rohrer, D. (2015). Student instruction should be distributed over long time periods. Educational Psychology Review, 27(4), 635-643. doi:10.1007/s10648-015-9332-4

Rose, K. (2000). An exploratory cross-sectional study of interlanguage pragmatic development. Studies in Second Language Acquisition, 22 (1), 27-67.

Safont, M. P. (2004). An analysis on EAP learners' pragmatic production: a focus on request forms. Iberica, 8, 23-39. 
Schauer, G. A. (2004). May you speaker louder maybe? Interlanguage pragmatic development in requests. In: S.H. Foster-Cohen, M. Sharwood Smith, A. Sorace, \& M. Ota (Eds.), EUROSLA Yearbook No. 4 (pp. 253-273). Amsterdam: John Benjamins.

Schauer, G. A. (2007). Finding the right words in the study abroad context: The development of German learners' use of external modifiers in English. Intercultural Pragmatics, 4(2), 193-220. doi:10.1515/ip.2007.011

Schauer, G. A. (2009). Interlanguage pragmatic development: The study abroad context. London: Continuum International Publishing Group.

Schmitt, N. (2010). Researching vocabulary: A vocabulary research manual. New York: Palgrave Macmillan.

Shardakova, M. (2013). “I joke you don't” Second language humor and intercultural identity construction. In C. Kinginger (Ed.), Social and Cultural Aspects of Language Learning in Study Abroad, (pp. 2017-238). Amsterdam: John Benjamins.

Shively, R. (2010). From the virtual world to the real world: a model of pragmatics instruction for study abroad. Foreign Language Annals, 43 (1), 105-137.

Shively, R. L. (2011). L2 pragmatic development in study abroad: A longitudinal study of Spanish service encounters. Journal of Pragmatics, 43(6), 1818-1835. doi:10.1016/j.pragma.2010.10.030

Shively, R. L. (2013). Out-of-class interaction during study abroad: Service encounters in Spain. Spanish in Context, 10(1), 53-91. doi:10.1075/sic.10.1.03shi

Shively, R. (2015). Developing interactional competence during study abroad: Listener responses in L2 Spanish. System, 48, 86-98

Takahashi, S. (2012). Individual differences and pragmalinguistic awareness: a structural equation modelling approach. Language, Culture, and Communication, 4, 103-125. 
Taguchi, N. (2006). Analysis of appropriateness in a speech act of request in L2 English. Pragmatics Quarterly Publication of the International Pragmatics Association (IPrA), 16(4), 513-533. doi:10.1075/prag.16.4.05tag

Taguchi, N. (2008). Cognition, language contact, and the development of pragmatic comprehension in a study-abroad context. Language Learning, 58(1), 33-71. doi:10.1111/j.1467-9922.2007.00434.x

Taguchi, N. (2014). Instructed pragmatics at a glance: Where ILP studies are, were, and should be going. Language Teaching, 48, 1-50.

Taguchi, N. (2015). “Contextually” speaking: A survey of pragmatic learning abroad, in class, and online. System, 48, 3-20. doi:10.1016/j.system.2014.09.001

Trosborg, A. (1995). Interlanguage Pragmatics: Requests, complaints, and apologies. Germany: De Gruyter Mouton.

Uso-Juan, E. (2010). Requests: A sociopragmatic approach. In A. Martinez-Flor \& E. UsoJuan (Eds.), Speech act performance: Theoretical, empirical and methodological issues (pp. 237-256). Amsterdam: John Benjamins Publishing Co.

Wang, V. X. (2011). Making requests by Chinese EFL learners. Netherlands: John Benjamins Publishing Co.

Wik, P., \& Hjalmarsson, A. (2009). Embodied conversational agents in computer assisted language learning. Speech Communication, 51, 1024-1037.

Winke, P. M., \& Teng, C. (2010). Using task-based pragmatics tutorials while studying abroad in china. Intercultural Pragmatics, 7(2), 363-399. doi:10.1515/iprg.2010.016

Woodfield, H. (2008). Interlanguage requests: A contrastive study. In M. Puetz \& J. Neff van Aertselaer (Eds.), Developing Contrastive Pragmatics: Interlanguage and Cross-cultural Perspectives (pp. 231-264). Berlin: Mouton de Gruyter. 
Woodfield, H. (2012). "I think maybe I want to lend the notes from you": development of request modification in graduate learners. In M. Economidou-Kogetsidis \& H. Woodfield (Eds.), Interlanguage request modification (pp. 9-50). Netherlands: John Benjamins Publishing Co.

Woodfield, H., \& Economidou-Kogetsidis, M. (2010). "I just need more time”: A study of native and non-native students' requests to faculty for an extension. Multilingua - Journal of Cross-Cultural and Interlanguage Communication, 29(1), 77-118.

doi:10.1515/mult.2010.004

Yang, H.-C., \& Zapata-Rivera, D. (2010). Interlanguage pragmatics with a pedagogical agent: The request game. Computer Assisted Language Learning, 23(5), 395-412.

Yu, M. (1999). Universalistic and culture-specific perspectives on variation in the acquisition of pragmatic competence in a second language. Pragmatics, 9(2), 281-312. doi:10.1075/prag.9.2.04yu

Zhang, Y. (1995). Indirectness in Chinese Requesting. In: G. Kasper (Ed.), Pragmatics of Chinese as native and target language (pp. 69-118). Hawai'i: University of Hawai'i Press. 